\title{
Localization of Human Malignant Tumors with Radioiodinated Recombinant Tissue Plasminogen Activator
}

\author{
Sirkka-Liisa Karonen, Hannu Aronen, Kristian Liewendahl, Päivi Nikkinen, \\ Matti Mäntylä, and Jan Lindgren \\ Department of Clinical Chemistry, Division of Nuclear Medicine, Department of Radiotherapy \\ and Oncology, Department of Bacteriology and Immunology, University of Helsinki, \\ 00290 Helsinki, Finland
}

\begin{abstract}
Human recombinant tissue plasminogen activator (tPA), labeled with ${ }^{131}$ ( $(1.1$ to $6.2 \mathrm{mCi})$ by the iodogen method, was administered intravenously to 15 patients with various soft-tissue malignant tumors after blocking of thyroidal radioiodine uptake. Gamma camera imaging was performed 4 and $24 \mathrm{hr}$ after injection; three patients were also imaged 5 days following injection. We observed accumulation of radioactivity in primary and secondary lesions in 11 patients. In this preliminary study we did not detect any definite association between the magnitude of uptake and type of tumor. Tumors were usually visualized already after $4 \mathrm{hr}$ but the uptake was more intense at $24 \mathrm{hr}$. The target-to-nontarget ratios at $24 \mathrm{hr}$, determined by computer analysis of stored images, varied from $<1.2$ to 2.1. This is the first demonstration of accumulation of radiolabeled tPA in malignant tissue. We do not know the mechanism of the uptake but because tPA is known to be avidly bound to fibrin, a component of the stroma of many malignant tumors, it is possible that [ $\left.{ }^{131}{ }^{1}\right]$ tPA is bound to fibrin rather than taken up by the malignant cell; various possible cell uptake mechanisms are discussed. Due to the relatively earty maximal uptake of this radiopharmaceutical it will be possible to substitute ${ }^{123}$ for ${ }^{131} \mathrm{I}$, a possibility suggesting a potential clinical use of radioiodinated tPA for the detection of malignant tumors of various origin.
\end{abstract}

J Nucl Med 29: 1194-1199, 1988

$\mathrm{M}$ alignant tumors often contain more plasminogen activator activity than corresponding normal tissue although the variation in this activity between histologically similar tumors is considerable $(1,2)$. It is possible that plasminogen activators participate in the regulation of the extracellular proteolytic activities necessary for the infiltration of malignant tumors through the basement membrane (3). However, there is some evidence that only the urokinase-like and not the tissue-type plasminogen activator possesses infiltration promoting properties (4). After homogenization of tissues the tissue plasminogen activator (tPA) remains strongly bound to cell particles and can only be solubilized using chaotropic agents (5). It has a high binding affinity for

Received June 29, 1987; revision accepted Jan. 27, 1988.

For reprints contact: Sirkka-Liisa Karonen, $\mathrm{PhD}$, Dept. of Clinical Chemistry, Division of Nuclear Medicine, Helsinki University Hospital (Meilahti), 00290 Helsinki, Finland.

- This study was presented in part at the European Nuclear Medicine Congress, Budapest, Hungary, August 24-28, 1987. fibrin (6), a component of the stroma of malignant tumors (7). The N-terminal portion of tPA (A-chain) contains fibrin binding activity and has a certain homology with epidermal growth factor (8). Since tumor tissue generally produces more tPA than the corresponding normal tissue, these $\mathrm{N}$-terminal sequences might exert a positive feedback function in malignant cells and even stimulate tumor growth (5). We have therefore evaluated a new approach to the localization of malignant tumors by radiolabeling recombinant tPA for use as a tumor probe. In experiments using a human adenocarcinoma cell line in the nude mouse we observed accumulation of radioiodinated TPA in the tumor (unpublished data). The aim of this study was therefore to test if tPA labeled with radioiodine can be used for the detection of malignant tumors.

\section{PATIENTS AND METHODS}

Tissue plasminogen activator (tPA) was obtained commercially (Boehringer Ingelheim International GmbH, FRG), and 
labeled with iodine-131 ( $\left.{ }^{131} I\right)$ using the iodogen method. Labeling efficiency was $60-70 \%$, and the calculated specific activity of $\left[{ }^{131} \mathrm{I}\right] \mathrm{tPA}$ was $4-6 \mathrm{mCi} / \mathrm{mg}$. Labeled tPA was checked for residual fibrinolytic activity using a dual-isotope technique ([ $\left.{ }^{125} I\right]$ fibrin clot versus $\left[{ }^{131} I\right]$ tPA or standard).

All patients examined had malignant tumors or metastatic lesions verified histologically and radiologically ( $x$-ray or computed tomography). There were 11 men and four women in this series. The ages ranged from 32 to 82 yr (mean $58 \mathrm{yr}$ ). The detailed description of the patient material is presented in Table 1. The protocol of the study was approved by the Ethical Committee of the Helsinki University Hospital and was in accordance with the Declaration of Helsinki.

After blocking of thyroidal radioiodine uptake by oral potassium iodide and perchlorate (daily dose $420 \mathrm{mg}$ and 800 $\mathrm{mg}$, resp., for 10 days) the patients received an intravenous injection of $\left[{ }^{131} \mathrm{I}\right] \mathrm{tPA}$. The administered dose of radioactivity ranged from 1.1 to $6.2 \mathrm{mCi}$ and the administered dose of protein from 0.3 to $1.0 \mathrm{mg}$. The distribution of radioactivity was studied 4 and $24 \mathrm{hr}$ after the injection using a large fieldof-view gamma camera. In three cases, gamma camera imaging was repeated 2 and 5 days after the injection. Computer analysis of images was performed for determination of targetto-nontarget radioactivity ratios.

Tumor tissue perfusion was measured by a xenon washout method $(9,10)$ in two patients; four lesions were studied.

\section{RESULTS}

The results of [ $\left.{ }^{131} I\right]$ tPA scintigraphy performed in 15 patients with primary malignant tumors and/or metastases are presented in Table 1 . In 11 patients accumulation of radioactivity was observed in at least one

TABLE 1

Accumulation of ${ }^{131} \mathrm{I}$-Labeled Tissue Plasminogen Activator in Various Malignant Primary and Secondary Tumors

\begin{tabular}{|c|c|c|c|c|c|c|c|}
\hline $\begin{array}{l}\text { Case } \\
\text { no. }\end{array}$ & Age/sex & $\begin{array}{l}\text { Dose } \\
\text { (mCi) }\end{array}$ & Diagnosis & Location of lesion & $\begin{array}{c}\text { Size of } \\
\text { lesion }(\mathrm{cm})\end{array}$ & $\begin{array}{l}\text { Scan } \\
\text { finding }\end{array}$ & $\begin{array}{c}\text { Target-to- } \\
\text { nontarget ratio }\end{array}$ \\
\hline 1 & $38 / F$ & 1.1 & Breast cancer & $\begin{array}{l}\text { Right breast } \\
\text { Liver, ovarian mets }\end{array}$ & $\begin{array}{r}5 \\
<3\end{array}$ & $\begin{array}{l}\text { Neg } \\
\text { Neg }\end{array}$ & - \\
\hline 2 & $66 / M$ & 4.9 & Prostatic cancer & $\begin{array}{l}\text { Recurrency (RT) } \\
\text { Pelvic, lumbar and } \\
\text { clavicular mets }\end{array}$ & $\begin{array}{l}13 \\
<2\end{array}$ & $\begin{array}{l}\text { Neg } \\
\text { Neg }\end{array}$ & - \\
\hline 3 & $65 / M$ & 5.4 & Small cell lung cancer & $\begin{array}{l}\text { Left lung } \\
\text { Brain met }\end{array}$ & $\begin{array}{l}4 \\
2.5\end{array}$ & $\begin{array}{l}\text { Pos } \\
\text { Pos }\end{array}$ & $\begin{array}{l}<1.2(24 \mathrm{hr}) \\
1.3(4,24 \mathrm{hr})\end{array}$ \\
\hline 4 & $73 / M$ & 2.4 & Hypernephroma & Lung mets & $<3.5$ & Neg & - \\
\hline \multirow[t]{2}{*}{5} & $32 / M$ & 4.2 & Melanoma & $\begin{array}{l}\text { Brain met } \\
\text { Brain met }\end{array}$ & $\begin{array}{l}3.5 \\
2.5\end{array}$ & $\begin{array}{l}\text { Pos } \\
\text { Pos }\end{array}$ & $\begin{array}{l}1.5(24 \mathrm{hr}) \\
1.5(24 \mathrm{hr})\end{array}$ \\
\hline & & & & Subcutaneous mets & $<1$ & Neg & - \\
\hline \multirow[t]{2}{*}{6} & $70 / M$ & 4.7 & Bronchial adenocarcinoma & $\begin{array}{l}\text { Left hilus + regional } \\
\text { mets (RT) }\end{array}$ & 6 & Neg & - \\
\hline & & & & Brain met & 2.5 & Pos & $1.3(4 \mathrm{hr})$ \\
\hline \multirow[t]{3}{*}{7} & $82 / F$ & 1.8 & Utinary bladder cancer & Urinary bladder (RT) & 4 & Neg & - \\
\hline & & & & Liver mets & $<3$ & $\mathrm{Neg}$ & - \\
\hline & & & & Diffuse lung mets & $<1$ & Neg & - \\
\hline \multirow[t]{3}{*}{8} & $69 / M$ & 6.2 & Small cell lung cancer & Right lung (RT) & 3 & Neg & - \\
\hline & & & & Brain met & 3 & Pos & $\begin{array}{l}1.4(4 \mathrm{hr}) \\
1.7(24 \mathrm{hr})\end{array}$ \\
\hline & & & & Liver mets & $<6$ & Pos & $<1.2(24 \mathrm{hr})$ \\
\hline 9 & $37 / M$ & 4.9 & Neuroepithelioma & Recurrency in neck & 7 & Pos & $1.4(4 \mathrm{hr})$ \\
\hline 10 & $81 / M$ & 5.1 & Histiocytoma & Right ploura & 12 & Pos & $1.2(24 \mathrm{hr})$ \\
\hline \multirow[t]{2}{*}{11} & $36 / M$ & 5.0 & Gastric adenocarcinoma & Thoracic wall met & 3 & Pos & $<1.2(24 \mathrm{hr})$ \\
\hline & & & & $\begin{array}{l}\text { Mets in liver, para- } \\
\text { aortic and clavicular } \\
\text { areas }\end{array}$ & $<2$ & Neg & - \\
\hline 12 & $47 / F$ & 6.2 & Melanoma & $\begin{array}{l}\text { Thoracic wall met } \\
\text { Subcutaneous mets }\end{array}$ & $\begin{array}{r}6 \\
<2\end{array}$ & $\begin{array}{l}\text { Pos } \\
\text { Neg }\end{array}$ & $\begin{array}{c}1.3(4,24 \mathrm{hr}) \\
-\end{array}$ \\
\hline \multirow[t]{2}{*}{13} & 48/M & 5.0 & $\begin{array}{l}\text { Esophageal squamous } \\
\text { cell cancer }\end{array}$ & $\begin{array}{l}\text { Met in left neck } \\
\text { (RT) }\end{array}$ & 3 & Pos & $1.8(24 \mathrm{hr})$ \\
\hline & & & & $\begin{array}{l}\text { Mets in left neck } \\
\text { (RT) }\end{array}$ & $<1$ & Neg & 一 \\
\hline \multirow[t]{2}{*}{14} & $63 / M$ & 5.0 & Epidermoid lung cancer & Met in left arm & 6 & Pos & $\begin{array}{l}1.4(4 \mathrm{hr}) \\
2.1(24 \mathrm{hr})\end{array}$ \\
\hline & & & & $\begin{array}{l}\text { Thoracic wall and } \\
\text { brain mets }\end{array}$ & 1.5 & Pos & $1.2(24 \mathrm{hr})$ \\
\hline 15 & $65 / F$ & 5.8 & $\begin{array}{l}\text { Adenocarcinoma of rec- } \\
\text { tum }\end{array}$ & $\begin{array}{l}\text { Met in right lung } \\
\text { Bilateral lung mets }\end{array}$ & $\begin{array}{r}5 \\
<2\end{array}$ & $\begin{array}{l}\text { Pos } \\
\text { Neg }\end{array}$ & $\begin{array}{c}1.2(24 \mathrm{hr}) \\
-\end{array}$ \\
\hline
\end{tabular}

'Radiotherapy administered before scintigraphy. 
lesion. Scintigrams from patients with positive findings are presented in Figure 1-4.

Four patients had no uptake of $\left[{ }^{131} \mathrm{I}\right] \mathrm{tPA}$ in malignant lesions. Three of these patients received doses of radioactivity ranging from 1.1 to $2.4 \mathrm{mCi}$, whereas patients with positive findings were administered doses of 4.2 to $6.2 \mathrm{mCi}$. One patient with a negative finding (Case 2) received $4.9 \mathrm{mCi}$ of labeled substance. In this case the tumor had been irradiated before scintigraphy. Nonvisualization of irradiated primary lesions was also recorded in Cases 6, 7, and 8. However, in Case 13 an irradiated metastatic lesion was found to accumulate [131] I]PA.

When irradiated tumors are excluded a clear association between size of lesion and uptake of $\left[{ }^{131} \mathrm{I}\right] \mathrm{tPA}$ can be observed from data presented in Table 1. Positive tumors varied in size from 2.5 to $12 \mathrm{~cm}$ (maximal diameter reported), except for the $1.5 \mathrm{~cm}$ or smaller metastatic lesions in Case 14. Negative tumors had a diameter varying from $<1$ to $5 \mathrm{~cm}$. There was no apparent association between scintigraphic findings and location of tumor in this initial series of patients.

All accumulations of $\left[{ }^{131} \mathrm{I}\right]$ tPA observable $24 \mathrm{hr}$ after injection were also visualized after $4 \mathrm{hr}$, except for two lesions, showing that uptake of this radiopharmaceutical is usually quite rapid. The target-to-nontarget radioactivity ratios at $24 \mathrm{hr}$ varied from $<1.2$ to 2.1 . Three lesions with a ratio $<1.2$ (ratios lower than 1.2 could not be accurately determined) were detected by inspection of the scintigrams. The uptake of radioactivity

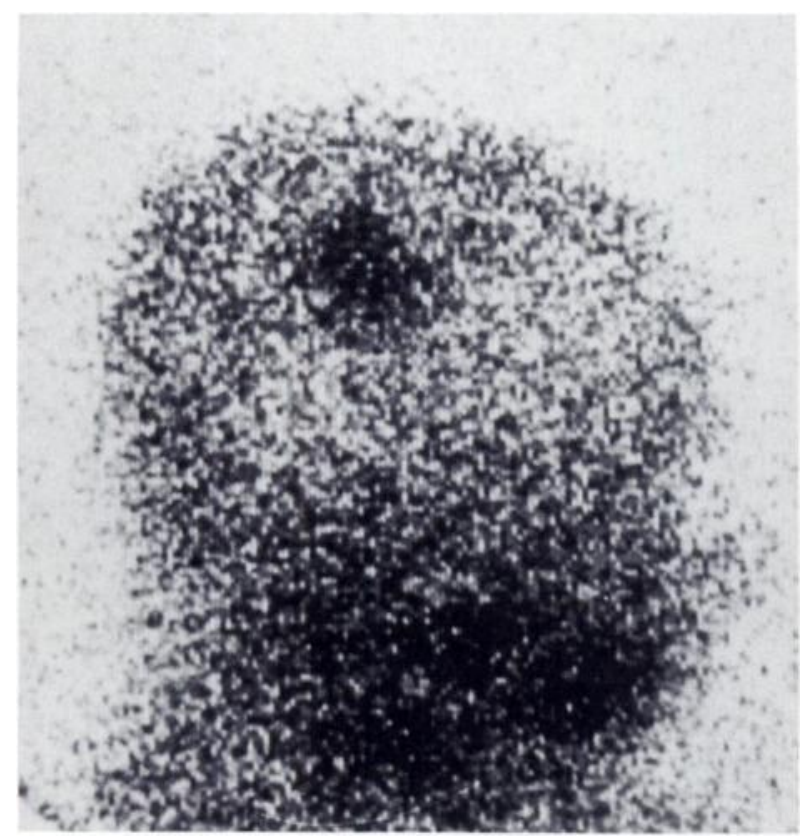

FIGURE 1

Accumulation of ${ }^{131} \mathrm{I}$-labeled tissue plasminogen activator $\left(\left[{ }^{131}\right]\right]$ tPA) in brain metastasis of lung carcinoma (Patient 8).

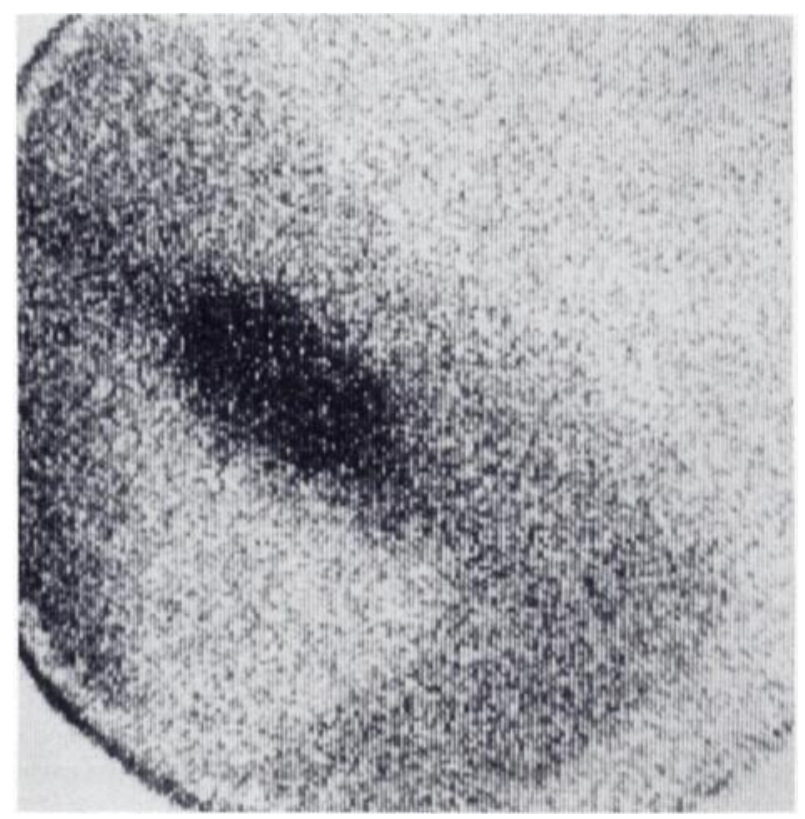

\section{FIGURE 2}

Concentration of $\left[{ }^{131} 1\right]$ tPA in metastasis of lung carcinoma in left upper arm (Patient 14).

observed in all three patients studied also 5 days after the injection indicates that release of radioactivity from lesion is slow.

Tumor blood perfusion was studied in two patients tissue. In Case 12 the perfusion rate was $30 \mathrm{ml} / \mathrm{min} /$ $100 \mathrm{~g}$ in a $2-\mathrm{cm}$ metastasis in the abdominal wall, and $60 \mathrm{ml} / \mathrm{min} / 100 \mathrm{~g}$ in a $6-\mathrm{cm}$ metastasis in the thoracic wall. In Case 14 the perfusion rate was $11 \mathrm{ml} / \mathrm{min} / 100$ $\mathrm{g}$ in a $1.5 \mathrm{~cm}$ subcutaneous metastasis in the thoracic area, and $28 \mathrm{ml} / \mathrm{min} / 100 \mathrm{~g}$ in a $6-\mathrm{cm}$ metastasis in the left upper arm.

For the purpose of obtaining information on biodistribution tPA labeled with ${ }^{131} \mathrm{I}(5.1 \mathrm{mCi})$ was injected intravenously into a 22-yr-old male patient with treated low-grade astrocytoma (patient not included among the 15 cases presented in the table). Dynamic measurement of radioactivity in the liver, spleen and heart was started immediately after the injection. In the liver maximal radioactivity was reached after $15 \mathrm{~min}$ and in the spleen after 9 min (Fig. 5). After reaching maximum $20 \%$ of the radioactivity in the liver and $10 \%$ of radioactivity in the spleen was eliminated during the next $15 \mathrm{~min}$. After $24 \mathrm{hr}$ the radioactivity in the liver was $2 \%$ and in the spleen $<1 \%$ of maximum.

No adverse reactions towards radiolabeled tPA were observed.

\section{DISCUSSION}

Human IPA is a single-chain polypeptide consisting of 527 amino acids. Its apparent molecular weight has been reported to range from 66,000 to 72,000 depend- 

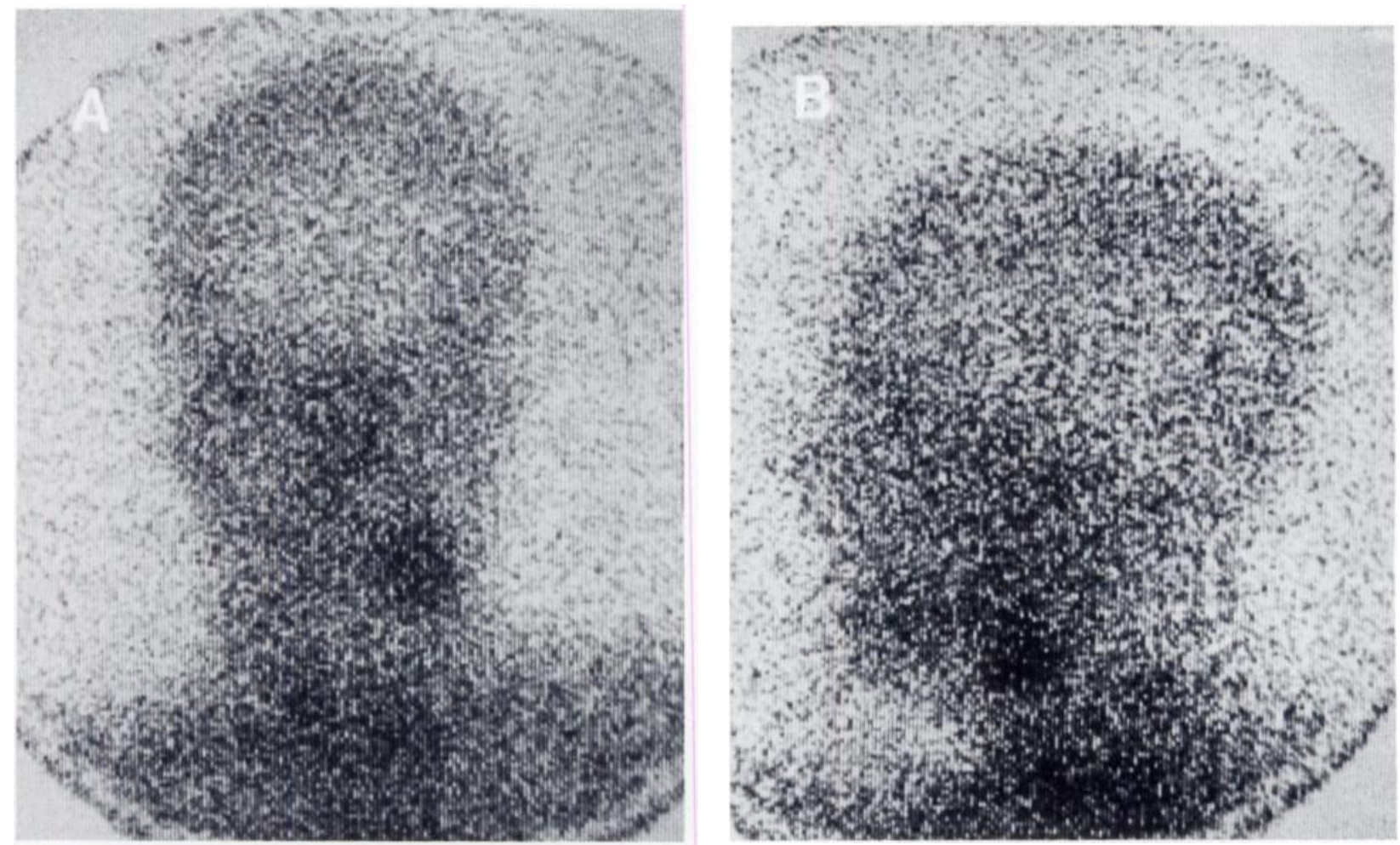

FIGURE 3

Uptake of $\left.\left[{ }^{131}\right]\right]$ tPA in metastasis of esophagus carcinoma in left neck. $A=$ anterior view, $B=$ lateral view (Patient 13).

ing on its source. The $\mathrm{N}$-terminal portion of the tPAmolecule contains two structures which are similar to the "kringles" found in plasminogen and prothrombin and a region which shows homology with the "fingerlike" structure in fibronectin $(11,12)$. The carboxyterminal portion of tPA shows considerable homology

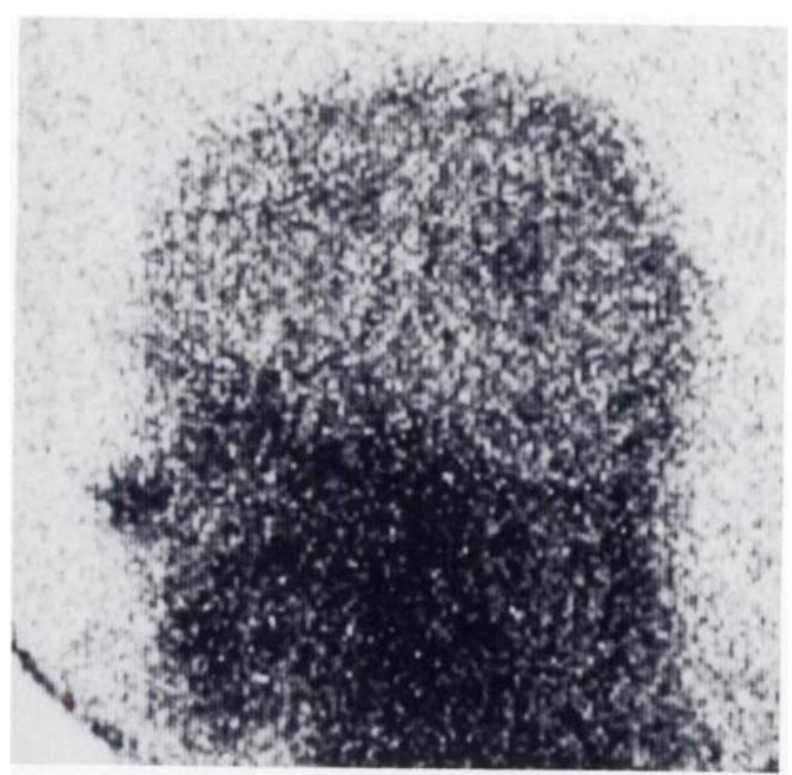

FIGURE 4

Accumulation of $\left[{ }^{131} 1\right]$ tPA in two brain metastases of malignant melanoma (Patient 5). with other serine proteases (13). After binding to fibrin tPA divides into two parts, an A-chain and a B-chain; the proteolytic activity of the B-chain is over 100 times that of the original molecule. Besides the kringles and

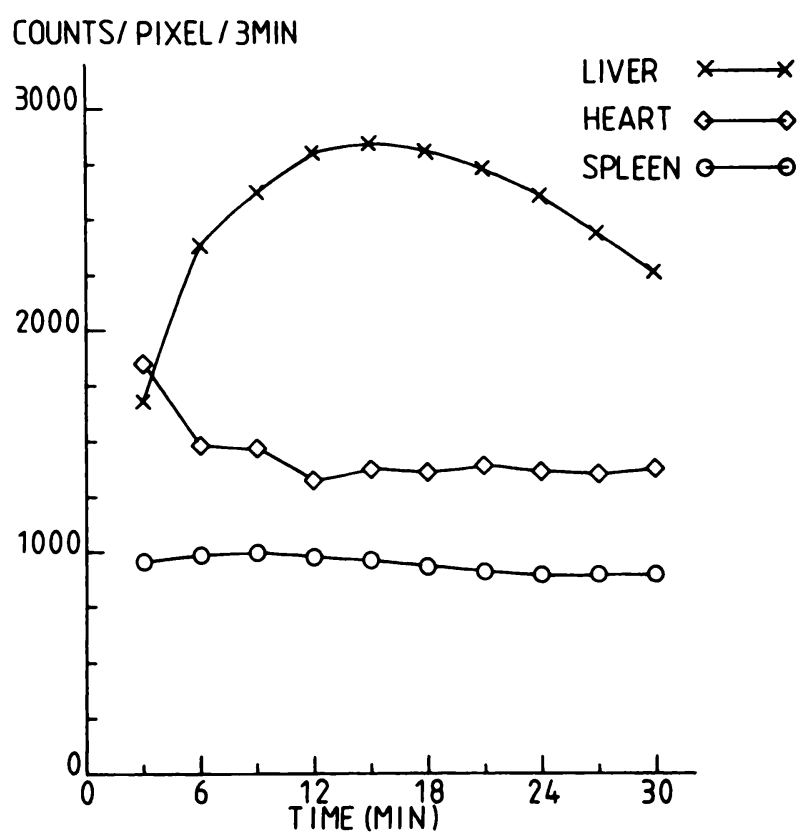

FIGURE 5

Time-activity curves of liver, heart, and spleen after intravenous injection of ${ }^{131}$-labeled tissue plasminogen activator $(5.1 \mathrm{mCi})$ in male patient. 
the finger-like structure, there is a growth factor domain in TPA showing homology with epidermal growth factor (EGF). Plasminogen activator mediated events may also initiate inactivation of EGF receptors (14). tPA is also an estradiol-inducible protein and therefore a potential marker for functional estrogen and progestin receptors, at least in breast cancer (15). In contrast, neither total plasminogen activator activity nor urokinase-like activity showed any significant correlation with either estrogen or progestin receptors. Dexamethasone and transforming growth factor beta (TGF $\beta$ ) have similar effects on tPA; both cause a significant decrease in total plasminogen activator activity. The effect is mainly due to the rapid synthesis of plasminogen activator inhibitors in the cells and not an inhibition of tPA synthesis. EGF antagonizes the inhibitory effects of TGF $\beta$ by enhancing synthesis of plasminogen activator. Thus, steroid hormones and growth factors modulate the proteolytic balance of the cell $(16,17)$.

Solid tumors are composed of malignant cells intermingled with stroma. Our results show that radioiodinated tPA accumulates in malignant tumors. The radioactivity might therefore be located in the stroma and not in the malignant cell. Small lesions were usually not detected and cases with negative findings usually received smaller doses of radioactivity and protein than cases with positive findings. It is therefore apparent that lesion size and dose of radioactivity or protein administered are factors influencing the detectability of tumors. In this initial series of patients we did not discover any clear association between the magnitude of uptake and type or locale of tumor. Neither was there evidence of a relationship between the degree of uptake and the vascularity of the tumor; the highest perfusion rate, 60 $\mathrm{ml} / \mathrm{min} / 100 \mathrm{~g}$, was observed in a lesion with a targetto-nontarget ratio of only 1.3 , whereas in a lesion with an uptake ratio of 1.8 the perfusion rate was $28 \mathrm{ml} /$ $\mathrm{min} / 100 \mathrm{~g}$. Importantly, this also shows that $\left[{ }^{131} \mathrm{I}\right] \mathrm{tPA}$ accumulation is not dependent on necrosis or thrombosis of the tumor.

Radiation therapy can cause fibrosis and it is therefore possible that radiation could enhance accumulation of tPA in the tumors. However, in Case 14 uptake of $\left.{ }^{131} I\right]$ tPA in the upper arm metastasis was actually lower in a second imaging study performed after radiation therapy, and in Cases 2, 6, 7, and 8 previously irradiated tumors did not accumulate tracer. Because radiation therapy seems to decrease or even prevent uptake of $\left[{ }^{131} I\right]$ tPA, scintigraphy should be performed before such therapy is administered.

In conclusion, this is the first demonstration of accumulation of radiolabeled tissue plasminogen activator in malignant tumors. At this stage, we do not know the mechanism of the uptake of this bioactive protein but because it is avidly bound to fibrin, a component of the stroma of malignant tumors, it is possible that it is bound to fibrin rather than to the malignant cell, although a close association between IPA activity and estrogen receptor function as well as growth factor activity has been established. Due to the relatively early maximal uptake of tissue plasminogen activator it will be possible to substitute ${ }^{123} I$ for ${ }^{131} I$, a possibility suggesting a potential clinical use of radioiodinated plasminogen activator for the detection of tumors of various origin and monitoring their response to therapy.

\section{REFERENCES}

1. Bigbee WL, Jensen RH. Characterization of plasminogen activator in human cervical cells. Biochim Biophys Acta 1978; 540:285-294.

2. Booth NA, Bennett B, Wijngaards G, et al. A new lifelong hemorrhagic disorder due to excess plasminogen activator. Blood 1983; 61:267-275.

3. Gelister JSK, Mahmoud M, Lewin MR, et al. Plasminogen activators in human colorectal neoplasia. $\mathrm{Br}$ Med J 1986; 293:728-731.

4. Danö K. Urokinase-type plasminogen activator in cancer. XIV Annual Meeting of the International Society for Oncodevelopmental Biology and Medicine. Helsinki 1986; Abstract 74.

5. Bachmann F, Kruithof EKO. Tissue plasminogen activator: chemical and physiological aspects. Semin Thromb Hemost 1984; 10:6-17.

6. Wallen P. Activation of plasminogen with urokinase and tissue activator. In: Paoletti R, Sherry S, eds. Thrombosis and urokinase. London: Academic Press 1977:91-102.

7. Dvorak HF, Senger DR, Dvorak AM. Fibrin as a component of the tumor stroma: origins and biological significance. Cancer Metas Rev 1983; 2:41-73.

8. MacGregor IR, Prowse CV. Tissue plasminogen activator in human plasma measured by radioimmunoassay. Thromb Res 1983; 31:461-474.

9. Mäntylä MJ. Regional blood flow in human tumors. Cancer Res 1979; 39:2304-2306.

10. Mäntylä MJ, Toivanen JT, Pitkänen MA, et al. Radiation-induced changes in regional blood flow in human tumors. Int J Radiat Oncol Biol Phys 1982; 8:1711-1717.

11. Banyai L, Varadi A, Patthy L. Common evolutionary origin of fibrin-binding structures of fibronectin and tissue-type plasminogen activator. FEBS Lett 1983; 163:37-41.

12. Pennica D, Holmes WE, Kohr WJ, et al. Cloning and expression of human tissue-type plasminogen activator CDNA in E. coli. Nature 1983; 301:214-221.

13. Strassburger W, Wollmer A, Pitts JE, et al. Adaptation of plasminogen activator sequences to known protease structures. FEBS Lett 1983; 157:219-223.

14. Gross JL, Krupp MN, Rifkin DB, et al. Down-regulation of epidermal growth factor receptor correlates with plasminogen activator activity in human A431 epidermoid carcinoma cells. Proc Natl Acad Sci 1983; 80:2276-2280.

15. Duffy MJ, O'Grady P, Simon J, et al. Tissue-type plasminogen activator in breast cancer. relationship with estradiol and progesterone receptors. $J$ Natl Cancer Inst 1986; 77:621-623. 
16. Laiho M, Saksela O, Andreasen PA, et al. Enhanced production and extracellular deposition of the endothelial-type plasminogen activator inhibitor in cultured human fibroblasts by transforming growth factor- $\beta$. J Cell Biol 1986; 103:2403-2410.
17. Gelehrter TD, Szyncer-Laszuk R, Zeheb R, et al. Dexamethasone inhibition of tissue-type plasminogen activator (tPA) activity: paradoxical induction of both tPA antigen and plasminogen activator inhibitor. $\mathrm{Mol}$ Endocrinol 1986; 1:97-101. 